\title{
The Relationship between Nominal Exchange Rate and Sectoral Output: An Emprical Analysis
}

\author{
Prof. Dr. Ahmet Ay (Selçuk University, Turkey) \\ Asst. Prof. Dr. Şerife Özşahin (Necmettin Erbakan University, Turkey) \\ Ph.D. Candidate Mustafa Gerçeker (Selçuk University, Turkey)
}

\begin{abstract}
In this study, it is investigated the existence of the long term relationship between nominal exchange rate and sectoral output for seven different sectors in Turkey by using control variables including money supply, total public expenditure, oil price and unemployment rate. For this purpose, possible relations are tried to be determined by using bound test and ARDL method for the period 1998 Q1-2011 Q3 with quarterly data. As a result of the bound test, it is achieved that there is a long term relationship in all sectors excluding construction. Based on this finding, it is estimated the long term coefficients and equations for the six sectors. These long term coefficients indicate that the rise in the TL/dollar nominal exchange rate affects sectoral output negatively in all sectors excluding finance because of the cost effects of imported input usage.
\end{abstract}

\section{Introduction}

By collapsing of Bretton Woods system in 1973, many countries - especially developed countries started to use floating exchange rate instead of fix exchange rate. Since this transition process cause serious fluctuation in exchange rate and trigger the economic uncertainties, it directed policy makers and researchers to investigate the effect of these fluctuations on the trade volume and production balance (Köse et al., 2008:26).

It is accepted that the devaluation that means depreciation of a currency or depreciating it by an administrative decision, will make cheaper the countries' exported products in terms of foreign currency and provide competitive advantage in export (Krugman and Taylor, 1978:445). The findings of many empirical studies about this subject show that, making a definite inference about the effect of decrease in nominal value on domestic production volume is not possible and that this interaction can be both positive and negative. In this respect, it is argued that the final effect on the domestic production volume will depend on the total demand and total supply curves' reaction to the decrease in value. If depreciation increases the total demand (due to the increase in net export) more than the decrease in total supply (due to the increase in the cost of imported inputs), it can be said that there will be an expansionist effect (Bahmani-Oskoee and Mirzaie, 2000: 51).

Clearly, that the foreign goods become more expensive as a result of depreciation of national currency, reduce the consumer demands for the imported goods and increase the demands for domestic products. In addition, it increases the demand for exported goods which become relatively cheaper. Furthermore, that the foreigners shift their expenditures to the imported goods which are cheaper than their domestic goods increase the export in the other foreign trade partner country, whose import decreases. It provides an improvement in current account balance of the country and then it makes an expansionist effect in all economy (Krugman and Obstfeld, 2000: 444-445). On the other hand, in the literature there are also other statement about that devaluations can be contractionary, in other words, changing in real exchange rate can have negative effects on the output volume. According to the studies about this statement, nominal devaluations' negative real balance effect cause decrease in real output by repressing the total demand and output level, due to the high price level (Edwards, 1986: 501). Krugman and Taylor (1978) states that devaluations can cause negative effects on output volume since both import and export are not sensitive to the changes in price in the short-run. Also, in the short-run when nominal wages are solid, increase in import of intermediate good cause redistribution of total revenue against the workers. In the case of that the national currency appreciates or revaluates, contrary interpretation can be made.

There are studies about the effects of changes in nominal exchange rate on the total production of country and sectoral output volume on the basis of sub-sectors. In this study, it is aimed to empirically examine the effects of changes in nominal exchange rates on the sectoral production volume with econometric methods by utilizing the methodology of Bahmani-Oskoee and Mirzaie's (2000) study on USA economy.

\section{Literature}

Although there are lots of studies about the effect of depreciation or appreciation on the total output level, it is seen that in both domestic and foreign literature there is not enough study about the exchange rate volatility effects especially on the sectoral base. In this respect, the limited number of studies on the relationship between the exchange rate and sectoral output level and the studies about the relationship between changes in exchange rates and total output can be summarized as follows. 
Bahmani-Oskoee and Mirzae (2000) examined the long termed relationship between production volume and dollar value in eight different sectors of US economy with co- integration method. In the study, the sectors of "agriculture, forestry, fishery"; "manufacturing"; "wholesale"; "retailing"; "finance, insurance and real estate"; "service"; "mining"; and "building" were considered. Even though the findings of Joahnsen co-integration test point out that there is one co-integration vector in each sector, co-integration relationship could not be identified due to the emergence of crowding out in many sectors and the relation between sectorial output and effective exchange rates.

Agenor (1991) studied the effect of real exchange rates on the output with the data of 23 countries for the period of 1978-1987. Empirical analysis is based on total output equation with the imported intermediate goods, derived from macro model of rational expectation. The findings of analysis reveal that the expected depreciations in the exchange rates have a negative effect on the economic activity, while the unexpected depreciations have a positive effect on the output.

Branson and Love (1986), examined the effect of fluctuations in the exchange rate on the output of manufacturing industry and the employment volume. They concluded that the fluctuations of exchange rate have significant effects on the output volume of manufacturing industry. According to this finding, depreciation of dollar has an expansionary effect on the production volume in a number of sectors.

Gylfason and Schmid (1983) studied the effects of $\% 10$ devaluation on the real output for 10 countries including US. The prediction coefficients of the parameters and flexibility values show that the devaluation increases the volume of real output in US economy.

Ibrahim (2007) analyzed the relationship between real effective exchange rates and total output volume and the output level of eight sub-sectors for Malaysia with a method similar to the study of Bahmani-Oskoee and Mirzae (2000). In the study, multivariable co-integration analysis was applied and it was found that there is a cointegration relationship between both the volume of total output and all sectors and real effective exchange rate.

Kandil and Mirzae (2000) examined the relationship between the exchange rate fluctuations and economic activities through the example of US. As a result of the study, by taking into consideration both supply and demand aspect of variations in the exchange rate, they showed that the exchange rate variations have a minimal effect on the industrial production.

Masunda (2011) examined the effects of deviation in exchange rate on the agriculture, manufacturing, and mining sectors for Zimbabwe. As a result of econometric analysis, it was concluded that the imbalances in the real exchange rate have a negative effect on the production volume. Another important result of the study is that overvaluation in exchange rate has a negative effect on the production volume of the sectors under consideration.

Aguirre and Calderon (2005) analyzed the effects of the deviation and volatility in exchange rates on the economic growth for 60 countries by using panel data method with the data including the period of 1965 -2003. According to the findings, although that incomplete valuation is at high levels affects growth negatively, incomplete valuation at reasonable levels affects the growth positively. In other words, economic growth is affected negatively from the real exchange rates at high level volatility and deviation.

Toulaboe (2000), analyzed what way the deviations in exchange rate affect economic growth rates of the developing countries and used the data per capita GDP growth rate and deviation in exchange rate of 33 developing countries. The results show that the deviations in the real exchange rate have negative correlation with the economic growth.

İşcan (1997), with the data including the years of 1978 -1991, examined the effect of nominal devaluation on the real output of nine different sectors of Mexican economy. In the study, the sectors of agriculture, fishery, and forestry; manufacturing; mining; building; financing; and insurance; service, transportation and communication; hotel and restaurant; and electric and energy were considered. According to the findings of the study, it was identified that devaluation had contractionary effect in the short run for the sectors except agricultural sector.

Sar1 (2009), in the sample of Turkey, with the monthly data including the period of 1986:10-2006:01, examined the effects of the increases in the exchange rate volatility, interest rates, and money supply on the total output. The findings of the study show that in Turkey, manufacturing sector was affected from the exchange rate volatility rather than interest volatility. According to this statement, the uncertainty in the exchange rate negatively affects the amount of sectorial production volume through import and export.

Ay et al. (2008) examined the causality relationship between the real exchange rate and output volume in Turkish economy with the quarterly data belonging to the period of 1990: Q1 - 2006: Q3. In the study, the real GDP variables for the output level and the real effective exchange rate variable for the exchange rate were used. Based on the empirical analysis result, in Turkey, it was suggested that the real exchange rate had positive effects on the output volume.

Çatık (2007) studied, in the sample of Turkish economy, the effect of the variations in real exchange rate on the economic growth, using Granger causality test, variance decomposition and cause-effect analyses. According 
to the findings of the study, since the real exchange rate kept below the balance value in Turkey, it can be said that the real exchange rate decreases the output volume in the long-run.

Uğurlu (2009) examined the relationship between the real exchange rate and the economic growth in Turkey, by establishing two different models. According to the results of Granger causality test, applied in the study, it was concluded that real exchange rate Granger cause GDP. The results of cause-effect and variance decomposition analysis suggested that the increases in the real exchange rate had an increasing effect on GDP in the short term, but this had a reducing effect in the long term.

\section{Data Set and Econometric Model}

In this study, the relationship between the sectorial output level and TL/USD nominal effective exchange rate is attempted to be determined with model used in the study of Bahmani-Oskooee and Mirzaie (2000) and expressed in Equation 1.

$$
Q_{i t}=F\left[W N_{t}, O N L P_{t}, G_{t}, M_{t}, E X_{t}\right]
$$

$Q_{\text {it }}$ that is present in Equation 1 represents the level of total output for each sector, ${ }^{U N} N_{t}$ the rate of unemployment, $O I L P_{t}$ oil prices, $G_{t}$ public expenditure, $M_{t}$ the real M2 money supply, and $E X_{t}$ nominal effective exchange rate in dollar. In addition econometric analyses were conducted through 7 different models, according to that each level of output is accepted as a dependent variable. For this purpose, the sectorial definitions used can be explained as follows:

$Q_{1}$ : Total output of agriculture, forestry, and fishery sector

$Q_{2}:$ Total output volume of manufacturing sector

$Q_{3}$ : Total output volume of transporting sector

Q.: Total output of building sector

$Q_{5}:$ Total output of financial and fiscal sector

$Q_{6}:$ Total output volume of service sector

$Q_{7}:$ Total output level of mining sector

According to Bahmani-Oskooee and Mirzaie (2000), the variable $U N_{t}$ included in the model so that it represents business circle, is expected to be negative due to the fact that the increase in unemployment rate causes the decrease in the total demand and at the production level of each sector. In addition, since increase in oil prices will increase the production cost in each sector, it causes consumers to pay for higher price. Hence, since the rise in oil price is a factor affecting the sectorial output level negatively, it is expected that the variable OILP $P_{t}$ also have negative sign. In case that the fiscal and monetary policies create an expansionary effect on the sectorial demand, the coefficients of the variables $G_{t}$ and $M_{t}$ are positive signed, otherwise, negative signed. In case that the rise in the exchange rate creates an expansionary effect on the sectorial output volume, the variable $E X_{t}$ representing the nominal effective exchange rate has a negative signed coefficient, while in case that this sign is positive, it can be said that the contractionary effects of the variations in exchange rate are more dominant.

In the study, the quarterly data belonging to the period of 1998.Q1-2011.Q3 is used in modeling by making their logarithmic transformations and the package program Eviews 6.1 is used for econometric analysis. Total output levels for each sector, nominal effective exchange rate, M2 real money supply, and time series of the public expenditures were compiled from Electronic Data Distribution system in the official internet page of TR Central Bank. In addition, the values associated with the unemployment rates were drawn from the database of Turkish Statistical Institute, while oil prices from that of State Planning Organization.

\section{Methodology}

Granger and Newbold (1974) mention about that the predicted model by using non-stationary time series will be spurious regressions and that the coefficients and signs achieved from these models will not reflect the real relationship. Hence, in all analyses using time series, stationarity test has a great importance. For this purpose, in order to test the presence or stationarity of possible unit roots in series, a number of method was developed, but among the frequently used method in the literature, ADF and PP tests draw attention.

\subsection{Unit Root Tests}

In ADF test developed by Dickey and Fuller (1981), three different regression are predicted according to the cases of that the data are constant, constant trend and non-constant. The models to be predicted in applying ADF test are expressed in Equations 2, 3, and 4. 


$$
\begin{aligned}
& \Delta Y_{t}=\delta Y_{t-1}+\sum_{t=1}^{m} \alpha_{i} Y_{t-1}+w_{t} \\
& \Delta Y_{t}=\beta_{1}+\delta Y_{t-1}+\sum_{i=1}^{m} \alpha_{i} Y_{t-i}+w_{t} \\
& \Delta Y_{t}=\beta_{1}+\beta_{2} t+\delta Y_{t-1}+\sum_{t=1}^{m} \alpha_{i} Y_{t-i}+w_{t}
\end{aligned}
$$

$u_{t}$ that is present in the equations represents the error correction term, while $Y_{t-1}$ represents the lagged value of one period of the dependent variable. In ADF test, the presence of unit root is tested with that $\delta$ equals to 0 and a decision is given by comparing these values calculated to the critical MacKinnon values (Gujarati, 2004: 817). In the stage of decision, accepting the alternative hypothesis by rejecting the null hypothesis, in other words, the calculated value should be smaller than the value of critical table for the series to be stationary.

Unit root tests of Phillips and Perron, as a method settling that the error terms from the regression equation are related to each other and the problem of the varying variance was developed by Phillips and Perron. This method can be explained by Equation 5 (Zivot and Wang, 2006:127).

$$
\Delta y_{t}=\beta D_{t}+\pi y_{t-1}+w_{t}
$$

The fact that the error term $\left(w_{t}\right)$ in Equation 5 includes unit root and the problem of possible varying variance is eliminated by correcting test statistics $t_{\pi=0}$ and $T \hat{\pi}$ in this method. It is decided whether or not the series is stationary, by comparing the calculated value to the critical value, just as in ADF test. That the calculated value is much smaller than the critical value, shows that the series do not include unit root also in PP test, in other words, that it is stationary.

\subsection{Bound Test and ARDL Method}

Engle and Granger (1987) and Johansen and Juselius (1990) co-integration tests emerged for testing the presence of inter - variables long termed relationships. These tests necessitate the stationarity at the same level in the series which the long termed relationship will be researched within, and these methods are not used in the case where this condition is not fulfilled. Bound test and ARDL method is the best in case that the series is stationary at the different level.

In bound test developed by Pesaran et al. (2001), first of all, presence of inter -series long termed relationship is researched. If the results of bound test point out a finding that there is a relationship, the short termed coefficients are achieved from ARDL method developed by Pesaran and Shin (1999). In this study, in order to research the effect of variations in the exchange rate on the sectorial output, it is used the methodology in the study of Bahmani-Oskooee and Mirzaie (2000). For this purpose, the regression equation to be predicted can be expressed as follows:

$$
Q_{t}=\beta_{0}+\beta_{1} U N_{t}+\beta_{2} O I L P+\beta_{3} G_{t}+\beta_{4} M_{t}+\beta_{5} E X_{t}+\varepsilon_{t}
$$

In bound test, developed by Pesaran et al., (2001), an unlimited error correction model, aligned according to the dependent variable, is predicted. According to the levels of sectorial output, the dependent variable of this study, the unlimited conditioned error correction model is shown in Equation 7.

$$
\begin{aligned}
\Delta Q_{t}= & c_{0}+c_{1} t+\delta_{1} Q_{t-1}+\delta_{2} U N_{t-1}+\delta_{3} O I L P_{t-1}+\delta_{4} G_{t-1}+\delta_{5} M_{t-1} \\
& +\delta_{6} E X_{t-1}+\sum_{i=1}^{p} \lambda_{i} \Delta Q_{t-i}+\sum_{i=0}^{p} \omega_{i} \Delta U N_{t-i}+\sum_{i=0}^{p} \varphi_{i} \Delta O I L P_{t-i} \\
& +\sum_{i=0}^{p} \gamma_{i} \Delta G_{t-i}+\sum_{i=0}^{p} \theta_{i} \Delta M_{t-i}+\sum_{i=0}^{p} \eta_{i} \Delta E X_{t-i}+u_{t}
\end{aligned}
$$

$\mathrm{c}_{0}$ in Equation 7 represents the constant term; $\Delta$, the first difference of the variables; and ${ }_{1}, \delta_{2}, \delta_{3}, \delta_{4}, \delta_{5}$ and $\delta_{6}$, long termed coefficients of the variables. In the first stage of bound test, the equation in Equation 7 is predicted with the lag lengths suggested by $p$ lag values Akaike (AIC) and Schwarz (SBC) information criteria. In determining the lag length, it is very important that there is no autocorrelation problem with the models predicted by this lag length (Pesaran and Shin, 1999: 373, 386).

The presence of inter - variables long term relationship will be decided as a result of that F-statistical values of the predicted regressions are compared with the critical values given by Pesaran et al..(2001). F-critical statistics given by Pesaran et al. (2001) give two statistical values; lower and upper limits. In case that the calculated F- 
value is bigger than critical upper limit of Pesaran et al. (2001), it can be said that there is along termed relationship (Pesaran et al., 2001: 290)

In the cases, where the findings of bound test point out the presence of long term relationship, the long and short termed regression equations will be achieved from ARDL method. The long term conditioned ARDL model, formed according to the appropriate lag length achieved at the stage of limit test is expressed in Equation 8.

$$
\begin{aligned}
Q_{t} & =c_{0}+\sum_{i=1}^{p_{1}} \alpha_{i} Q_{t-i}+\sum_{i=0}^{q_{1}} \theta_{1 i} U N_{t-i}+\sum_{i=0}^{q_{2}} \theta_{2 i} O I L P_{t-i}+\sum_{i=0}^{q_{3}} \theta_{3 i} G_{t-i} \\
& +\sum_{i=0}^{q_{4}} \theta_{4 i} M_{t-i}+\sum_{i=0}^{q_{5}} \theta_{5 i} E X_{t-i}+u_{t}
\end{aligned}
$$

The equation of error correction model, in which the short termed coefficients of variables will be achieved, takes place in Equation 9.

$$
\begin{aligned}
\Delta Q_{t} & =\mu+\sum_{i=1}^{p} \lambda_{i} \Delta Q_{t-i}+\sum_{i=0}^{p} \omega_{i} \Delta U N_{t-i}+\sum_{i=0}^{p} \varphi_{i} \Delta O I L P_{t-i} \\
& +\sum_{i=0}^{p} \gamma_{i} \Delta G_{t-i}+\sum_{i=0}^{p} \theta_{i} M_{t-i}+\sum_{i=0}^{p} \eta_{i} E X_{t-i}+\vartheta E C M_{t-1}+u_{t}
\end{aligned}
$$

The coefficients in front of each variable in Table 9 are the short termed coefficients of variables and the term $\vartheta$ represents the error correction coefficient of the model. For error correction model to run well, the error correction coefficient should be negative signed and statistically significant. In addition, for the reliability of short termed regression, it is necessary to apply Breusch-Godfrey autocorrelation test, Jarque-Bera normality test, and White varying variance test

\section{Results of Analysis}

In the methods of bound test and ARDL not requiring that the variables are stationary at the same level, even in the series having the stationarity at different level, the presence of long termed relationship can be tested. However, since these methods can be applied in case that the series is stationary in only first order differences, no series requires to be stationary its second order difference. In this study, to test the stationarity levels of series,

\begin{tabular}{|c|c|c|c|c|}
\hline & \multicolumn{2}{|l|}{ ADF } & \multicolumn{2}{|c|}{ Phillips-Perron } \\
\hline Variable & Constant & Constant and trended & Constant & Constant and trended \\
\hline Q1 & $-1.537(0.50)$ & $-2.188(0.48)$ & $-3.588(0.00)$ & $-6.830(0.00)$ \\
\hline Q2 & $-2.663(0.08)$ & $-2.011(0.58)$ & $-5.114(0.00)$ & $-2.141(0.51)$ \\
\hline Q3 & $-3.459(0.01)$ & $-1.855(0.66)$ & $-4.824(0.00)$ & $-1.619(0.77)$ \\
\hline $\mathrm{Q} 4$ & $-2.542(0.11)$ & $-1.771(0.70)$ & $-6.673(0.00)$ & $-1.956(0.61)$ \\
\hline $\mathrm{Q} 5$ & $-2.535(0.11)$ & $-4.331(0.00)$ & $-2.598(0.09)$ & $-4.159(0.00)$ \\
\hline Q6 & $-3.667(0.00)$ & $-3.047(0.13)$ & $-6.772(0.00)$ & $-2.442(0.35)$ \\
\hline Q7 & $-5.438(0.00)$ & $-0.818(0.95)$ & $-1.869(0.34)$ & $-4.324(0.00)$ \\
\hline UN & $-2.647(0.09)$ & $-3.631(0.03)$ & $-2.464(0.12)$ & $-3.543(0.04)$ \\
\hline OILP & $-1.456(0.54)$ & $-3.825(0.02)$ & $-0.993(0.74)$ & $-2.873(0.17)$ \\
\hline G & $-5.698(0.00)$ & $-3.357(0.06)$ & $-7.140(0.00)$ & $-3.391(0.06)$ \\
\hline $\mathrm{M}$ & $-8.785(0.00)$ & $-5.111(0.00)$ & $-7.718(0.00)$ & $-6.703(0.00)$ \\
\hline EX & $-1.881(0.33)$ & $-1.594(0.78)$ & $-1.881(0.33)$ & $-1.594(0.78)$ \\
\hline \multicolumn{5}{|c|}{ Critical Values } \\
\hline$\% 1$ & -3.557 & -4.137 & -3.557 & -4.137 \\
\hline$\% 5$ & -2.916 & -3.495 & -2.916 & -3.495 \\
\hline$\% 10$ & -2.596 & -3.176 & -2.596 & -3.176 \\
\hline
\end{tabular}
it is used Expended Dickey-Fuller Unit Root Test (ADF), developed by Dickey and Fuller (1981), and PhillipsPerron (PP) unit root test by Phillips and Perron (1988). In Table 1, it is reported the results of ADF and PP unit root test of the original series that its logarithmic transformation is made.

Table 1: The results of $A D F$ and PP Unit Root Test of the original series

Table 1 reports the findings of ADF and PP tests in two different ways, constant and trended. When the results of ADF and PP tests were evaluated; it is seen that the stationarity levels belonging to the series differentiate according to the sort of test and according to that models are constant and trended. Whether or not the series not 
turning out stationary at level is stationary in their first differences requires ADF and PP tests to be applied, taking the first differences of all series. In Table 2, the results of stationarity test of the series that its first difference is taken, are given place.

\begin{tabular}{|l|l|l|l|l|}
\hline \multicolumn{3}{|l|}{ ADF } & \multicolumn{2}{l|}{ Phillips-Perron } \\
\hline Variable & Constant & Constant and Trended & Constant & Constant and Trended \\
\hline Q1 & $-1.359(0.59)$ & $-1.280(0.88)$ & $-16.06(0.00)$ & $-15.872(0.00)$ \\
\hline Q2 & $-1.853(0.35)$ & $-3.045(0.13)$ & $-8.536(0.00)$ & $-11.988(0.00)$ \\
\hline Q3 & $-2.752(0.07)$ & $-4.086(0.01)$ & $-7.390(0.00)$ & $-9.805(0.00)$ \\
\hline Q4 & $-2.854(0.05)$ & $-3.547(0.04)$ & $-6.461(0.00)$ & $-10.769(0.00)$ \\
\hline Q5 & $-7.060(0.00)$ & $-7.165(0.00)$ & $-9.375(0.00)$ & $-10.069(0.00)$ \\
\hline Q6 & $-1.344(0.60)$ & $-1.668(0.75)$ & $-6.571(0.00)$ & $-8.113(0.00)$ \\
\hline Q7 & $-1.925(0.31)$ & $-13.923(0.00)$ & $-11.27(0.00)$ & $-15.952(0.00)$ \\
\hline UN & $-9.993(0.00)$ & $-9.984(0.00)$ & $-11.91(0.00)$ & $-12.83(0.00)$ \\
\hline OILP & $-6.118(0.00)$ & $-6.101(0.00)$ & $-5.354(0.00)$ & $-5.451(0.00)$ \\
\hline G & $-7.001(0.00)$ & $-9.407(0.00)$ & $-7.224(0.00)$ & $-9.438(0.00)$ \\
\hline M & $-3.569(0.00)$ & $-5.010(0.00)$ & $-3.374(0.01)$ & $-4.866(0.00)$ \\
\hline EX & $-7.123(0.00)$ & $-7.222(0.00)$ & $-7.123(0.00)$ & $-7.226(0.00)$ \\
\hline Critical Values & \multicolumn{3}{|l}{} \\
\hline$\% 1$ & -3.562 & -4.144 & -3.560 & -4.140 \\
\hline$\% 5$ & -2.918 & -3.498 & -2.917 & -3.496 \\
\hline$\% 10$ & -2.597 & -3.178 & -2.596 & -3.177 \\
\hline
\end{tabular}

Table 2: The results of ADF and PP Unit Root Tests of the series that its first difference is taken

When the findings in Table 2 are examined, it is seen that the series that is not stationary at the original level, becomes stationary in their first differences. Since it is seen that all series to be used in the econometric analysis are stationary at maximum first level; with a technical expression, that it is I(1), the presence of long term relationship can be tested.

To use the bound test for testing the presence of inter-variables long term relationships, Equation 7 should be predicted by an ordinary least squares method. In selection of suitable lag length stated as p in Equation 7, it is used generally the Akaike and Schwarz information criteria. In addition, in the model predicted with the lag length suggested by these information criteria, whether or not there is autocorrelation problem is controlled with Breusch-Pagan Lagrange multiplier (LM) and LM test results are summarized in Table 3.

\begin{tabular}{|l|l|l|l|l|l|l|l|l|}
\hline \multirow{2}{*}{ Models } & \multicolumn{3}{|c|}{ With Deterministic Trend } & \multicolumn{3}{|c|}{ Without Deterministic Trend } \\
\cline { 2 - 9 } & $\mathrm{p}$ & AIC & SCH & LM $(1)$ & $\mathrm{p}$ & AIC & SCH & LM $(1)$ \\
\hline Model 1 & 4 & 1.72 & 2.200 & $2.348(0.12)$ & 4 & 1.77 & 2.21 & $4.205(0.05)$ \\
\hline Model 2 & 4 & -2.62 & -2.143 & $1.788(0.18)$ & 4 & -2.58 & -2.14 & $3.364(0.06)$ \\
\hline Model 3 & 4 & -2.56 & -2.090 & $2.895(0.08)$ & 4 & -2.56 & -2.11 & $2.249(0.13)$ \\
\hline Model 4 & 4 & -2.40 & -1.922 & $0.008(0.92)$ & 1 & -2.40 & -1.95 & $0.101(0.74)$ \\
\hline Model 5 & 1 & -0.99 & -0.514 & $1.921(0.16)$ & 1 & -1.02 & -0.58 & $1.852(0.17)$ \\
\hline Model 6 & 4 & -2.11 & -1.638 & $0.404(0.52)$ & 4 & -2.15 & -1.71 & $0.406(0.52)$ \\
\hline Model 7 & 4 & -11.6 & -0.457 & $0.209(0.64)$ & 4 & -1.08 & -0.41 & $0.002(0.95)$ \\
\hline
\end{tabular}

Note: $\mathrm{p}$ is the appropriate lag length, while the values in parenthesis probability values.

\section{Table 3: Determination of appropriate lag length}

When the results in Table 3 are evaluated, it is seen that Akaike and Schwarz information criteria show the same lag length except for one model. The models predicted according to these lag length do not have autocorrelation problem according to Pagan Lagrange multiplication.

In Table 4, the results of bound test for trended and non -trended models take place. In bound test, in order to assign the presence of inter-series co-integration relationship, we need for the critical values given by Pesaran et al. (2001) and the calculated F-statistics. In case that the calculated F-statistics are bigger than the critical value given by Pesaran et al.(2001), it can be said that there is an inter-series long termed relationship and in this case, the null hypothesis will be rejected, the alternative hypothesis will be accepted. In Table 4, the results of limit test are given place. 


\begin{tabular}{|l|l|l|l|l|}
\hline \multirow{2}{*}{ Dependent variable } & \multicolumn{2}{|l|}{ Trended Model } & Non-trended Model & Result \\
\cline { 2 - 5 } & F-iv & F-v & F-iii & \\
\hline Agriculture & 4.025 & 4.407 & 4.563 & There is co-integration \\
\hline Manufacturing & 5.197 & 4.022 & 5.909 & There is co-integration \\
\hline Wholesaling & 8.714 & 9.092 & 9.952 & There is co-integration \\
\hline Building & 2.587 & 2.460 & 2.720 & There is no co-integration \\
\hline Finance & 4.321 & 4.723 & 5.124 & There is co-integration \\
\hline Service & 14.075 & 13.551 & 16.162 & There is co-integration \\
\hline Pesaranet al.(2001) lower limit critical values & Pesaranet al.(2001) upper limit critical values \\
\hline$\% 1$ & -3.43 & -4.79 & \\
\hline$\% 5$ & -2.87 & -4.19 & -3.86 \\
\hline$\% 10$ & -2.57 & &
\end{tabular}

Note: Critical values are from the study of Pesaran et al.(2001)

Table 4: F-statistics obtained from limit test and Critical values pertinent to Pesaranvd. (2001)

When the findings in Table 4 are compared with the lower and upper values of Pesaranet.(2001), it is seen that the values calculated with the other models are bigger than critical upper limit, except for the model, in which the sectorial output level of the building sector is dependent variable. Hence, in these models it can be said that there is a long term relationship and it can be moved to ARDL model, in which the long and short term coefficients of series will be obtained.

The reason for why there is no long-run relationship in the building sector can be understood with examining the input-output tables. When the last input-output table, published by TÜIK in 2002, is examined, it is seen that the building sector use domestic intermediate input at high level and that the amount of import input remains at very low level (TÜIK, 2002). Hence, that the use of imported input remains at the very low level is the cause of no long run relationship between the sectorial output level and the variation in the exchange rates for the building sector.

In the method of ARDL, the suggestion of Akaike criterion is used as lag length. Any prediction was not made for the model where the building sector is dependent variable since there is no long term relationship between them. In Table 5, it is given the results of ARDL method which established to obtain coefficients for evaluating the relationships in other sectors.

\begin{tabular}{|c|c|c|c|c|c|c|c|}
\hline & & UN & OILP & G & $M$ & EX & $\bar{C}$ \\
\hline \multirow{6}{*}{ 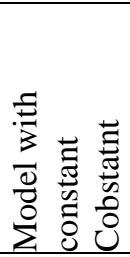 } & Agricl. & $-0.45^{* *}$ & $0.441^{*}$ & $0.892 * *$ & 0.122 & 0.016 & $18.48^{*}$ \\
\hline & Manuf. & $-0.529 *$ & -0.187 & $0.749 * *$ & 0.099 & $0.021 *$ & $20.22 *$ \\
\hline & Whsale & $-0.612^{*}$ & 0.047 & $0.804 * *$ & -0.038 & $0.034 *$ & $22.34 *$ \\
\hline & Finance & $0.881 *$ & 0.029 & -0.190 & 0.622 & -0.029 & 8.162 \\
\hline & Service & $-0.203^{*}$ & $0.121^{*}$ & $0.593^{*}$ & 0.062 & $0.032 *$ & $20.677^{*}$ \\
\hline & Mining & 0.110 & $0.204 *$ & 0.361 & $0.395 * *$ & 0.008 & $9.139^{*}$ \\
\hline \multirow{6}{*}{ 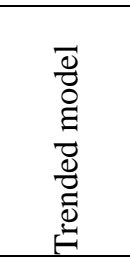 } & Agricl. & $-0.39 * *$ & 0.002 & $1.488 *$ & $-1.14 * *$ & $0.034 * *$ & $47.49 *$ \\
\hline & Manuf & $-0.550^{*}$ & $\begin{array}{l}-0.19 \\
\end{array}$ & $0.744 * *$ & 0.051 & $0.023^{* *}$ & $21.66^{*}$ \\
\hline & Whsale & $-0.571^{*}$ & 0.030 & $0.817^{* *}$ & 0.090 & $0.029^{* *}$ & $18.57^{*}$ \\
\hline & Finance & $0.828 * *$ & 0.105 & 0.298 & -0.215 & -0.027 & $27.666^{* *}$ \\
\hline & Service & $-0.190^{*}$ & $0.112 *$ & $0.615^{*}$ & 0.101 & $0.029^{*}$ & $19.399^{*}$ \\
\hline & Mining & 0.135 & $0.238^{*}$ & $0.514^{*}$ & $0.377 * *$ & 0.003 & $8.161 * * *$ \\
\hline
\end{tabular}

Table 5: ARDL Model Results and Long Term Co-efficient

When the long-run coefficients given in Table 5 are examined, in the sectors except for the financial and mining sectors, it is seen that with the decrease of total demand for the relevant sectors, the unemployment rate reduces the level of sectorial output. In all models except for the Model 7, where mining sector is dependent variable, the unemployment rate is a statistically significant variable affecting the sectorial output. In addition, the rise in oil prices also does not create a negative effect in any sector on the sectorial output except for manufacturing industry, where oil prices are used as an input. According to the long term coefficients come from the results of regression, it can be said that the increase in the public expenditures has an expansionary effects on the sectorial output in all models except for "the constant model" of the finance sector. In "the constant model" giving the effect of public expenditures on the finance sector, this variable is not statistically significant. When these coefficients are evaluated in terms of monetary policy it can be said that the monetary policy applied mostly affects the sectorial output positively.

When the effect of the variations in the exchange rates on the sectorial output is examined, in all sectors except for the financial sectors, it is seen that the rises in the exchange rates have statistically significant effects at the 
$1 \%$ level on the sectorial output in the constant models, at the $5 \%$ level in the trended model. On the other hand, increase in the nominal exchange rate has contractionary effect on the sectorial output except for the financial sector. However, even if the effect of increase in the exchange rate on the output volume of the financial sector is expansionary, this effect is not statically significant.

This positive contractionary interaction between the nominal exchange rate and the sectorial output can be explained by levels of imported input used in the sectors. When the input- output table published by TÜIK is examined, it is seen that these contractionary effects on the sectorial output volume emerge through the import channel due to the import input used in all the relevant sectors. Since rising exchange rates requires more payment for imported inputs, the cost pressure creates the decreasing effects on the sectorial output level.

Furthermore, although many sectors in the scope of the manufacturing industry have foreign trade surplus, adapting to the new technologies in order to provide continuity in the productivity growth, make it necessary to renew for the firms in this sector and this situation also makes the import continuously (Küçükkiremitçi, 2011). In addition, according to the results of analysis, that depreciation of domestic currency as a result of increase in the real exchange rate makes the import more expensive also explains the positive contractionary interaction between the input level in the manufacturing industry and the real exchange rate.

When the results are evaluated in terms of the agricultural sector, due to the fact that the amount of intermediate input of the agricultural sector is low and that it depends on the weather conditions, it can be suggested that there is no statistically significant relationship between the level of agricultural output and the exchange rates. Also, in the results of analysis this situation can be explained with the fact that the level of nominal exchange rate is not a significant variable affecting the output level of agricultural sector.

The coefficients that explain the short-run relationships between the variables can be obtained with error correction model, established in the basis of ARDL equation and expressed in Equation 9. In Table 6, the findings of coefficient that give the short term relationships between the variables are presented.

\begin{tabular}{|c|c|c|c|c|c|c|}
\hline & Agricl. & Manuf. & Wholesale & Finance & Service & Mining \\
\hline$\Delta Q_{1(t-1)}$ & $-0.22 * *$ & $-0.46 *$ & $-0.17 * * *$ & & $-0.10 * * *$ & 0.11 \\
\hline$\Delta Q_{i(t-2)}$ & $-0.58 *$ & $-0.44^{*}$ & $-0.24 *$ & & $-0.35^{*}$ & $-0.40^{*}$ \\
\hline$\Delta Q_{\mathrm{i}(\mathrm{t}-\mathrm{a})}$ & $-0.60 *$ & $-0.43^{*}$ & $-0.21 * *$ & & $-0.56^{*}$ & $-0.45^{*}$ \\
\hline$\Delta G$ & $0.60 *$ & 0.13 & -0.08 & 0.48 & -0.02 & -0.08 \\
\hline$\Delta G_{(0-1)}$ & & & $-0.48^{*}$ & $0.57 * * *$ & $-0.58^{*}$ & -0.18 \\
\hline$\Delta G_{(t-2)}$ & & & $-0.49 *$ & & $-0.40 *$ & $-0.50 * *$ \\
\hline$\Delta G_{(0-9)}$ & & & $-0.28 * *$ & & $-0.22 *$ & $-0.45 * *$ \\
\hline$\Delta M$ & 0.10 & -0.13 & 0.01 & 0.26 & -0.06 & $0.72 * *$ \\
\hline$\Delta M_{(t-1)}$ & $-0.94 * *$ & -0.11 & -0.22 & & $-0.31 *$ & -0.30 \\
\hline$\Delta M_{(t-2)}$ & & -0.10 & -0.03 & & -0.17 & $-0.69 * *$ \\
\hline$\Delta M_{(t-a)}$ & & $0.51 *$ & $1.06^{*}$ & & $0.33 *$ & $0.68 * *$ \\
\hline$\triangle U N$ & -0.10 & $-0.25^{*}$ & $-0.30 *$ & 0.14 & $-0.13^{*}$ & $0.16^{* * *}$ \\
\hline$\Delta U N_{(t-1)}$ & & & $0.10 * * *$ & & & -0.02 \\
\hline$\Delta U N_{(t-2)}$ & & & 0.02 & & & $-0.20 * *$ \\
\hline$\Delta U N_{(0-9)}$ & & & $0.12 * *$ & & & \\
\hline$\triangle E X$ & 0.00 & $0.01 *$ & $0.01 *$ & $0.07 *$ & $0.01 *$ & 0.00 \\
\hline$\Delta E X_{(t-1)}$ & -0.01 & & $-0.01 * *$ & $0.02 * *$ & $-0.01 *$ & \\
\hline$\Delta E X_{(t-2)}$ & $-0.03 *$ & & $-0.00 * * *$ & & $-0.01 *$ & \\
\hline$\Delta E X_{(0-8)}$ & & & $-0.01 * *$ & & & \\
\hline$\triangle O N L P$ & -0.07 & 0.05 & $0.14 *$ & 0.04 & 0.03 & 0.05 \\
\hline$\Delta O N L P_{(t-1)}$ & $0.24 * *$ & $0.22 *$ & $0.15^{*}$ & & $-0.03 * * *$ & -0.13 \\
\hline$\Delta O N L P_{(t-2)}$ & 0.13 & $0.12 *$ & $0.08 * * *$ & & 0.01 & \\
\hline$\triangle O N L P_{(t-a)}$ & $0.21 *$ & $0.17 *$ & $0.14 *$ & & $0.06 *$ & \\
\hline C & -0.00 & 0.00 & -0.00 & 0.00 & 0.00 & -0.00 \\
\hline $\operatorname{ECM}_{(t-1)}$ & $-0.81 *$ & $-0.52 *$ & $-0.79 *$ & $-0.56^{*}$ & $-1.11 *$ & $-1.36^{*}$ \\
\hline
\end{tabular}

Table 6: The results of ARDL model and error correction model and the short term coefficients

The term ECM, the error correction coefficient, is negative signed and statistically significant, as expected. When the short term relationships between the exchange rate and the sectorial output are examined it is seen that it is not possible to make an interference supporting the long termed findings in all sectors except for the finance and mining sectors. This is because of the fact that the relationships between the first and second lags of series and the sectorial output have different signs. The short term relationships between the changes in the exchange rate and the sectorial output are statistically significant except for mining sector. 


\section{Conclusion}

In this study, it is investigated the existence of the long term relationship between nominal exchange rate and sectoral output by using the methodology in Bahmani-Oskooeeand Mirzaie (2000). For this purpose, possible relations are analyzed by using bound test and ARDL method for the period 1998.Q1-2011Q3. For researching the presence of the relationship between nominal exchange rate and sectorial output volume, Turkish economy is evaluated in the basis of 7 sub-sectors including agriculture- forestry-fishery, manufacturing wholesale business, building, financial and fiscal agencies, service and mining. In this respect, first of all, ADF and PP unit root tests are applied for stationarity test. Then, in order to determine whether or not there is a long term relationship between the series, bound test is used and it is achieved that there are long term relationships in six sectors except for the building sector. The long term coefficients obtained from ARDL method, point out that increase in nominal exchange rate except for financial sector negatively affects the sectorial output level. In the sectors, especially in manufacturing industry, in which the use of sectorial input is intensive, increase of nominal exchange rate negatively affects the total output volume due to the cost effect it creates. However, even if this interaction in the agricultural sector, where the output level depends on the weather conditions and the mining sector, where the use of imported input remains at very low level is negative, it is not statistically significant.

\section{References}

- $\quad$ AGENOR, P.(1991). Output, devaluation and the real exchange rate in Developing Countries. Review of World Economics, 127(1), 18-41.

- $\quad$ AGUIRRE, A. ve CALDERON, C. (2005). Real exchange rate misalignments and economic performance. Central Bank of Chile Working Papers, Paper No: 315.

- $\quad$ AY, A., ŞAYLAN, Ş. ve KOÇAK, İ. (2008). Reel döviz kuru ve çıktı arasındaki nedensellik ilişkisi: Türkiyeörneği (1990-2006). S. Ü. İ̈BF SosyalveEkonomikAraştırmalarDergisi, 8(15), 361-374.

- BAHMANI-OSKOOEE, M. ve MIRZAIE, A. (2000). The long-run effects of depreciation of the dollar on sectoral output. International Economic Journal, 14(3), 51-61.

- $\quad$ BRANSON, W.H. ve LOVE, J.P.(1986). Dolar appreciation and manufacturing employment and output. NBER Working Paper Series, Working Paper No. 1972.

- ÇATIK, A.N.(2007). Daraltıcı devalüasyon hipotezi: Türkiye üzerine bir uygulama. Gazi Üniversitesi Ekonomik Yaklaşım Dergisi, 18(62), 61-79.

- $\quad$ DICKEY, D.A. ve WAYNE, F. (1981). Likelihood ratio statistics for autoregressive time series with a unit root. Econometrica, 49(4), 1057-1072.

- $\quad$ EDWARDS, S.(1986). Are devaluations contractionary. Review of Economics and Statistics, 68(3), 501-508.

- $\quad$ ENGLE, R.F. ve GRANGER, C.(1987). Co-integration and error correction: representation, estimation and testing. Econometrica, 55(2), 251-276.

- $\quad$ GRANGER, C.W. ve NEWBOLD, P. (1974). Spurious regressions in econometrics. Journal of Econometrics, 2(1974), 111-120.

- $\quad$ GUJARATI, D. (2004). Basic Econometrics. The Mcgraw Hill Companies.

- GYLFASON, T. ve SCHMID, M.(1983). Does devaluation cause stagflation?. The Canadian Journal of Economics, 16(4), 641-654.

- IBRAHIM, M.H. (2007). Sectoral effects of ringgit depreciation shocks. Journal of Economic Development, 32(2), 135-156.

- IŞCAN, T. (1997). Devaluations and aggregate output fluctuations: a random coefficient regression model for Mexico. Applied Economics, 29(12), 1575-1584.

- JOHANSEN, S. ve JUSELIUS, K. (1990). Maximum likelihood estimation and inference on cointegration. Oxford Bulltein of Economics and Statistics, 52(2), 169-210.

- $\quad$ KANDIL, M. ve MIRZAIE, A. (2002). Exchange rate fluctuations and disaggregated economic activity in the US: theory and evidence. Journal of International Money and Finance, 21, 1-31.

- KÖSE,N., AY,A. ve TOPALLI,N.(2008). Döviz kuru oynaklığının ihracata etkisi: Türkiye örneği (19952008). Gazi Üniversitesi İ̈BF Dergisi, 10(2), 26-45.

- $\quad$ KRUGMAN, P. ve TAYLOR, L. (1978). Contractionary effects of devaluation. Journal of International Economics, 8(1978), 445-456.

- $\quad$ KRUGMAN, P.R. ve OBSTFELD, M. (2000). International economics theory and policy. Addison-Wesley Publishing Company, 5th Edition.

- $\quad$ KÜÇÜKKİREMITÇi, O. (2011). Türkiye sanayi strateji belgesi temelinde imalat sanayinin yapısal analizi. Memleket, Siyaset, Yönetim, 15(2011), 53-94. 
- MASUNDA, S. (2011). Real Exchange Rate Misalgnment and Sectoral Output in Zimbabwe. International Journal Economic Research, 2(4), 59-74.

- $\quad$ PESARAN, H., YONGCHEOL, S. ve SHIN, R. (2001). Bounds testing approaches to the analysis of level relationship. Journal of Applied Econometrics, 16(3), 289-326.

- $\quad$ PERRON, P. ve PHILLIPS, P. (1988). Testing for a unit root in time series regression. Biometrica, 75(2), ss. 335-346.

- SARI, A. (2009). Çıktıya (GSMH) para arzındaki büyümenin, faiz oranı oynaklığı ve döviz kuru oynaklığının etkileri: Türkiye örneği. Afyon Kocatepe İ̈BF Dergisi, 11(2), 19-36.

- $\quad$ TOULABOE, D. (2006). Real exchange rate misalignment and economic growth in developing countries. Southwestern Economic Review, 33(1), 57-72.

- $\quad$ TÜİK (2002). Türkiye ekonomisinin arz kullanım ve girdi-çıktı tabloları.

- UĞURLU, E. (2009). Real exchange rate and economic growth: Turkey. Manas Üniversitesi Sosyal Bilimler Dergisi, 22, 191-212.

- $\quad$ ZIVOT, E. ve JIHAUI, W. (2006). Modelling Time Series with S-Plus. Springer, Second Edition, 